\title{
Pollen evidence of the palaeoenvironments of Lufengpithecus lufengensis in the Zhaotong Basin, southeastern margin of the Tibetan Plateau
}

\author{
Lin Chang ${ }^{\mathrm{a}, \mathrm{b}}$, Zhengtang Guo ${ }^{\mathrm{a}, \mathrm{c}, *}$, Chenglong Deng ${ }^{\mathrm{d}}$, Haibin $\mathrm{Wu}^{\mathrm{a}}$, Xueping Ji ${ }^{\mathrm{e}, \mathrm{f}}$, Yan Zhao ${ }^{\mathrm{g}}$, \\ Chunxia Zhang ${ }^{\mathrm{a}, \mathrm{c}}$, Junyi Ge ${ }^{\mathrm{c}, \mathrm{f}}$, Bailing Wu ${ }^{\mathrm{b}, \mathrm{d}}$, Lu Sun ${ }^{\mathrm{d}}$, Rixiang Zhu ${ }^{\mathrm{d}}$ \\ a Key Laboratory of Cenozoic Geology and Environment, Institute of Geology and Geophysics, Chinese Academy of Sciences, Beijing 100029, China \\ b University of Chinese Academy of Sciences, Beijing 100049, China \\ c CAS Center for Excellence in Tibetan Plateau Earth Sciences, Beijing 100101, China \\ d State Key Laboratory of Lithospheric Evolution, Institute of Geology and Geophysics, Chinese Academy of Sciences, Beijing 100029, China \\ e Department of Paleoanthropology, Yunnan Institute of Cultural Relics and Archeology, Kunming 650118, China \\ ${ }^{\mathrm{f}}$ Institute of Vertebrate Paleontology and Paleoanthropology, Chinese Academy of Sciences, Beijing 100044, China \\ ${ }^{\mathrm{g}}$ Institute of Geographic Sciences and Natural Resources Research, Chinese Academy of Sciences, Beijing 100101, China
}

\section{A R T I C L E I N F O}

\section{Article history:}

Received 29 November 2014

Received in revised form 4 May 2015

Accepted 2 June 2015

Available online 11 June 2015

\section{Keywords:}

Palaeovegetation

Pollen

Habitat

Hominoid

Late Miocene

Southeastern margin of the Tibetan Plateau

\begin{abstract}
A B S T R A C T
Evolutionary processes in hominoid primates were closely related to global and/or regional environmental changes, and therefore palaeoenvironmental reconstruction is fundamental for understanding how environmental changes shaped their evolution. Here, we present pollen data from the 16-m-thick Shuitangba (STB) section, Yunnan Province, southwestern China, bearing remains of the hominoid Lufengpithecus lufengensis of the terminal Miocene; and use principal component analysis to reconstruct the palaeovegetation and palaeoclimate during the key period when the hominoid lived. Our results show that before the STB hominoid appeared (Zone A), the vegetation was dominated by subtropical evergreen broad-leaved taxa with a few temperate deciduous taxa (e.g., Quercus, Castanea/Castanopsis, Alnus). The development of aquatic plants commencing at the $\sim 12 \mathrm{~m}$ depth is a prominent feature, indicating a warm and humid climate. During the time when the hominoid lived (Zone B), evergreen broad-leaved forests with evergreen Quercus were predominant, while grasses including Poaceae began to expand, and simultaneously conifers decreased, indicating a warm climate. The significant presence of aquatic pollen taxa in subzone A-2 and Zone B suggests the occurrence of lacustrine or swampy environments. In contrast, in Zone $C$, the vegetation changed to coniferous forest, indicating cooler and drier conditions. These results provide substantive evidence of the vegetation conditions when the hominoid lived, suggesting that the greater diversity of vegetation and the warm humid climate, compared to the present day, would have favoured its survival.
\end{abstract}

(C) 2015 Elsevier B.V. All rights reserved.

\section{Introduction}

Global and regional environmental changes are thought to have had a profound impact on the evolutionary processes of Cenozoic terrestrial mammals (Blois and Hadly, 2009) and hominoid primates (the apes and humans) (e.g., Bonnefille et al., 2004; deMenocal, 2004; Elton, 2008; Wood and Harrison, 2011; Potts, 2013; Antón et al., 2014; Maslin et al., 2014). Following their appearance in Africa around the Oligocene/ Miocene boundary (23 Ma) (Boschetto et al., 1992; Gebo et al., 1997), the various hominoid species lived in Africa, Europe and Asia during the Miocene, but with an uneven temporal and spatial distribution (Andrews, 1992; Benefit and McCrossin, 1995). Interestingly, there

\footnotetext{
* Corresponding author at: Key Laboratory of Cenozoic Geology and Environment, Institute of Geology and Geophysics, Chinese Academy of Sciences, Beijing 100029, China. Tel.: +8610 8299 8264; fax: +861062010846.

E-mail address: ztguo@mail.iggcas.ac.cn (Z.Guo).
}

appears to have been a flourishing of hominoid species in parts of East Africa and Europe, such as in Kenya, Ethiopia, Greece and Spain, around the mid-Miocene Climate Optimum (17-15 Ma) (Begun, 2002; Ward and Duren, 2002; Moyà-Solà et al., 2004). However, in the late Miocene (approximately 11.6-5.3 Ma), the number of ape taxa decreased sharply worldwide, and they became rare in Africa and parts of Asia. In Europe, hominoids became extinct after the Vallesian Crisis of the earliest Late Miocene (Agustí et al., 1997; Casanovas-Vilar et al., 2011), with the latest recorded in the Vallès-Penedès Basin, Spain at around 9.5 Ma (Agustí et al., 1997), or at Rudabánya, Hungary, at ca. 10-9.7 Ma (Bernor et al., 2004). It is noteworthy that the southeastern margin of the Tibetan Plateau, particularly in Yunnan, southwest China, served as an important refugium for the late Miocene hominoids (Zhu et al., 2005; Harrison, 2006; Ji et al., 2013). Despite numerous studies over more than three decades, the nature of the habitats of the late Miocene Yunnan hominoids remains contentious (Sun and Wu, 1980; Qiu et al., 1985; Chen et al., 1986; Pan and Zong, 1993; Wang, 1996; Qian and Ling, 1998; Liu et al., 
2002; Ni and Qiu, 2002; Xia et al., 2009; Biasatti et al., 2012). Moreover, the reasons for the existence of the refugium have rarely been discussed, especially in terms of the habitats of the hominoids, owing to the limited availability of high-resolution palaeoenvironmental data for this critical area.

Fortunately, a new hominoid fossil was recently discovered in the Shuitangba (STB) section, Zhaotong Basin, northeastern Yunnan, which was assigned to the species Lufengpithecus lufengensis and magnetobiostratigraphically dated at $6.2 \mathrm{Ma}$, the terminal Miocene (Ji et al., 2013). It is the latest Miocene fossil ape yet discovered throughout the world (Ji et al., 2013).

The terminal Miocene was a critical time interval for mammalian evolution, especially for the evolution of the apes and early humans. Climatic and environmental changes as well as tectonic processes during this critical period had a profound influence on their habitats, and thus may have led to important evolutionary events. For example, a marked change in palaeovegetation, especially an expansion of $\mathrm{C}_{4}$ plants, has been widely documented around the world in the late Miocene and Pliocene (e.g., Quade et al., 1989; Cerling et al., 1993, 1997, 2011; An et al., 2005; Huang et al., 2007). During this period, the divergence of ape and human lineages occurred in Africa (Brunet et al., 2002), and apes disappeared in Europe and later became extinct in East Asia (Harrison et al., 2002; Casanovas-Vilar et al., 2011). Therefore, the STB site provides a unique opportunity to determine the environment of this latest ape, and to further explore the relationship between environmental factors and hominoid primates' evolution.

In this paper, we present a detailed palynological record from the STB sedimentary sequence, which enables us to reconstruct the vegetation and environmental conditions during the period when the STB hominoid lived. Our discussion of the data focuses on the palaeovegetation changes at this time, which hopefully may yield improved insight into the relationship between the natural environment and the evolution history of hominoids in East Asia.

\section{Setting, materials and methods}

\subsection{Geology}

The Zhaotong Basin is located in northeastern Yunnan Province, on the southeastern margin of the Tibetan Plateau (Fig. 1). Covering an area of ca. $230 \mathrm{~km}^{2}$, the basin has an irregular, roughly oval shape, with a length of approximately $20 \mathrm{~km}$ from north to south and a width of approximately $15 \mathrm{~km}$ from west to east (Wang, 2010). It is one of the fault-related basins in the Xianshuihe-Xiaojiang fault zone, one of the major fault zones in the South China fold belts (Wang et al., 1998). The basin consists of a series of sub-basins or synclines, such as the Hehua, Zhugeying and Haizi synclines (Wang, 2010). Presently, these sub-basins or synclines are separated by hills.

The Zhaotong Basin is filled with the late Miocene to Pliocene lacustrine or swampy clays, silts, peaty clays and lignites (Chou and Zhai, 1962; Wang, 2010; Ji et al., 2013). Sediments rich in peaty clays are extensively distributed in the late Neogene basins of the southeastern margin of the Tibetan Plateau (Zhu et al., 2008; Biasatti et al., 2012; Li et al., 2013). Our samples were collected from the STB section $\left(27^{\circ} 19^{\prime}\right.$ $41.8^{\prime \prime} \mathrm{N}, 103^{\circ} 44^{\prime} 13.7^{\prime \prime} \mathrm{E}$, with a maximum elevation of $\sim 1930$ meters above sea level ( $m$ a.s.l.)), which is located in an open-pit lignite mine (Fig. 2) in the northwestern margin of the Zhugeying sub-basin of the Zhaotong Basin.

The outcropping STB section has a thickness of approximately $16 \mathrm{~m}$, and is composed of seven sedimentary units, including two lignite layers (Table 1 and Fig. 2). It should be noted that three lignite layers occur in the late Neogene sedimentary sequence of the Zhaotong Basin (Dai and Chou, 2007; Wang, 2010); however, the upper lignite layer is absent at the STB station (Jablonski et al., 2014). A new, relatively complete juvenile cranium of the fossil hominoid Lufengpithecus was excavated from the middle-upper part of the black peaty clay layer
(Ji et al., 2013), which is bracketed by the middle and lower lignite layers (see Unit \#6 in Table 1 and Fig. 2).

\subsection{Chronology}

Detailed magnetostratigraphic and biostratigraphic investigations of the STB section place stringent age controls on the hominoid-bearing strata (Ji et al., 2013; Jablonski et al., 2014). The recovered mammalian fauna from the section belongs to the East Asian Baodean Stage/Age (Ji et al., 2013; Jablonski et al., 2014), which is a standard terrestrial biochron for the late Miocene, from $\sim 7.25$ to $\sim 5.33 \mathrm{Ma}$ (Qiu et al., 2013). The recovered fauna from the section comprises biochronologically-useful taxa typical of the late Miocene to early Pliocene, such as Sinocastor, Kowalskia, Pliopetaurista, Alilepus and proboscideans (Ji et al., 2013; Jablonski et al., 2014). High-resolution magnetostratigraphy demonstrates that the STB sedimentary sequence spans the interval from upper chron C3An.2n to lower chron C3An.1n. The short intervening reverse chron C3An.1r is absent possibly due to the proximity of the section to the sub-basin margin. The hominoid-bearing sedimentary layer is located near the C3An.1r-C3An.1n transition (Ji et al., 2013). As a result, the sequence spans the interval from $\sim 6.73 \mathrm{Ma}$ to $\sim 6.03 \mathrm{Ma}$, and the hominoidbearing layer is estimated to be $\sim 6.2 \mathrm{Ma}$ in age, based on the Astronomically Tuned Neogene Time Scale of Hilgen et al. (2012) (ATNTS2012). Therefore, both magnetostratigraphic and biostratigraphic data unambiguously indicate a terminal Miocene age for the hominoid-bearing STB section.

\subsection{Modern vegetation}

The modern vegetational zone in the Zhaotong Basin and adjacent areas belongs to the south-subtropical evergreen broadleaved forest, which is the only primary broad-leaved forest distributed at 1500-2400 $\mathrm{m}$ a.s.l. The zonal vegetation mainly consists of evergreen trees, such as Quercus, Lithocarpus, Castanopsis, Fagus, Araliaceae, Hamamelidaceae, Magnoliaceae, Lauraceae, Theaceae, Ilex, Ericaceae and Rosaceae, mixed with several deciduous broadleaved trees of Betulaceae, Aceraceae and Nyssaceae. Other elements of the vertically-zoned vegetation include mountain coniferous and broad-leaved mixed forest at 2900-3200 m a.s.l., mountain cold coniferous forest at 3100-4100 $\mathrm{m}$ a.s.l., and subalpine shrubland and meadow above $4000 \mathrm{~m}$ a.s.l. (Jiang, 1980). In addition, a significant area of secondary forest has replaced the natural forest vegetation, which has been seriously damaged by the long-term effects of human activity (Editorial Committee for Vegetation of Yunnan, 1987).

\subsection{Materials and methods}

A total of 337 samples at a 5-cm interval were collected from the $16 \mathrm{~m}$-thick STB section. 27 samples were analyzed in this study, 14 from the hominoid-bearing layer $(8.70-9.25 \mathrm{~m})$ at a 5-cm interval, and 13 from the overlying and underlying sedimentary layers at a $\sim 1$-m interval.

For each sample, approximately $10 \mathrm{~g}$ of sediment was used for pollen analysis. The samples were treated with $\mathrm{HCl}(15 \%)$ and $\mathrm{NaOH}(\sim 3 \%)$ to remove carbonates and organic matters, respectively. Heavy liquid separation with $\mathrm{ZnI}_{2}$ (specific density $1.8 \mathrm{~g} / \mathrm{cm}^{3}$ ) was used to concentrate the pollen. Finally, silicates were removed using HF (40\%) and $\mathrm{HCl}$ (36-38\%) before mounting the palynomorphs in glycerin jelly (Fægri and Iversen, 1975; Xu et al., 2013). For most of the samples, more than 400 pollen grains were counted. The pollen and spore percentages for each taxon were calculated based on the sum of terrestrial pollen and total grains, respectively. Modern generic names were used for the identified taxa (Traverse, 1988), since most of the taxa encountered from the Late Miocene are extant. The pollen data were presented and analyzed using the Grapher and Tilia software packages. 
(a)

a)

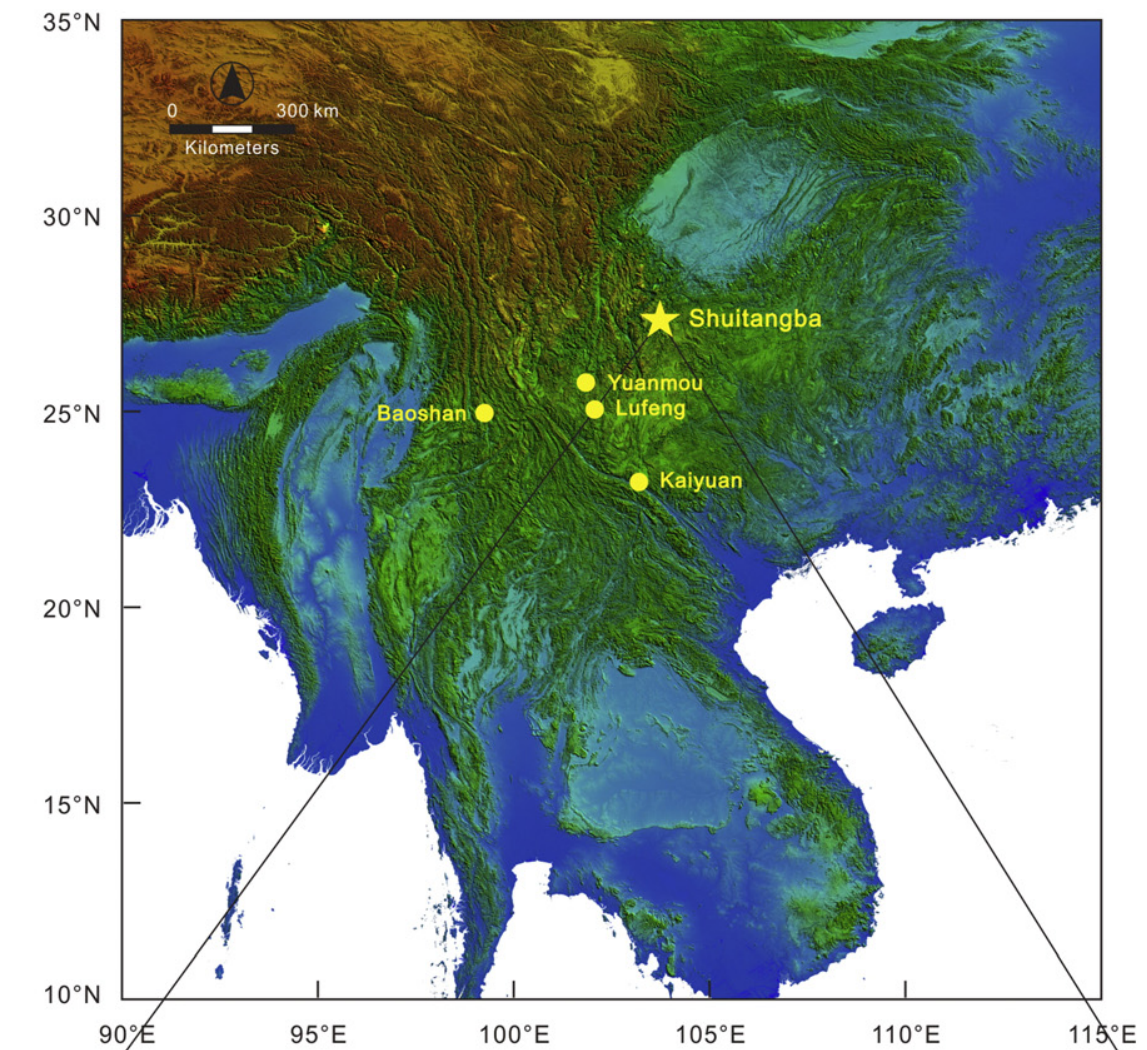

(b)
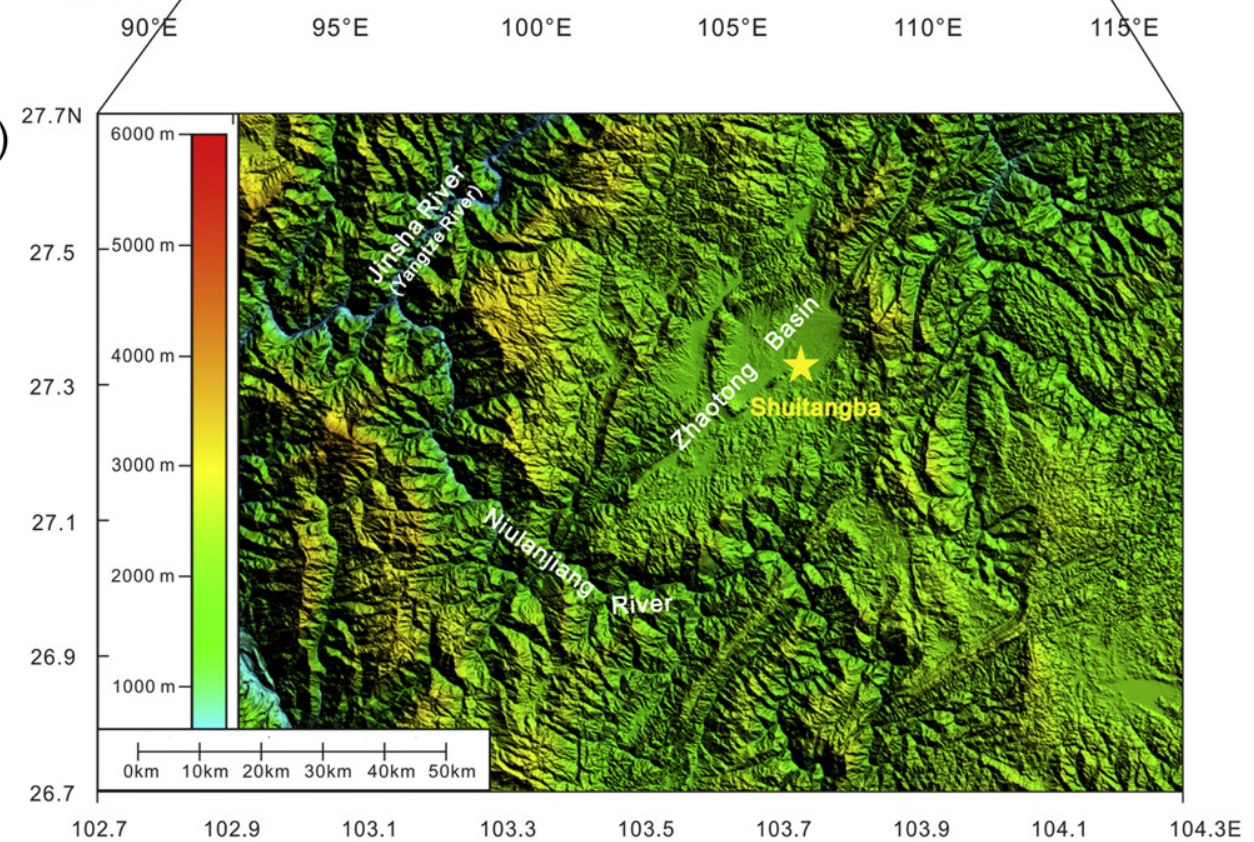

Fig. 1. Schematic map showing the principal late Miocene hominoid-bearing sites in Yunnan Province (a). Also shown in (b) is the Zhaotong Basin and its major fluvial system.

Using the C2 software, principal component analysis (PCA) was applied to the terrestrial pollen percentage data to reveal the main gradients of change in the vegetation. Only pollen taxa with a relative abundance of $>5 \%$ in at least two samples were used in the data analyses, in order to highlight the major trends.

\section{Results}

\subsection{Stratigraphic zonation based on pollen assemblages}

71 families and genera of pollen and spores were identified from all of the samples. Most are angiosperms (68.3\%), followed by gymnosperms
(21.2\%) and pteridophytes (10.5\%). The dominant species are Quercus-evergreen (Quercus E) (31.2\%) and Alnus (11.5\%). Pollen of Quercus-deciduous (Quercus D), Poaceae, Tsuga, Pinaceae, Carya, Castanea/Castanopsis and Ulmus occurs frequently. There are only a few occurrences of Ilex, Picea, Carpinus, Corylus, Oleaceae, Larix, Eriaceae, Liquidambar, Pterocarya, Apiaceae, Polygonaceae, Rutaceae, Melia, Elaeagnus, and Trapa. In addition, there are rare occurrences of Pediastrum, Zygnema, Spirogyra and some moss spores.

According to the variations of pollen percentages and the results of cluster analysis, we divided the pollen diagram into three zones, A, B and $C$, from the base to the top (Fig. 3). Zones $A$ and $C$ are further divided into subzones A-1 and A-2, and C-1 and C-2, respectively (Fig. 3). 


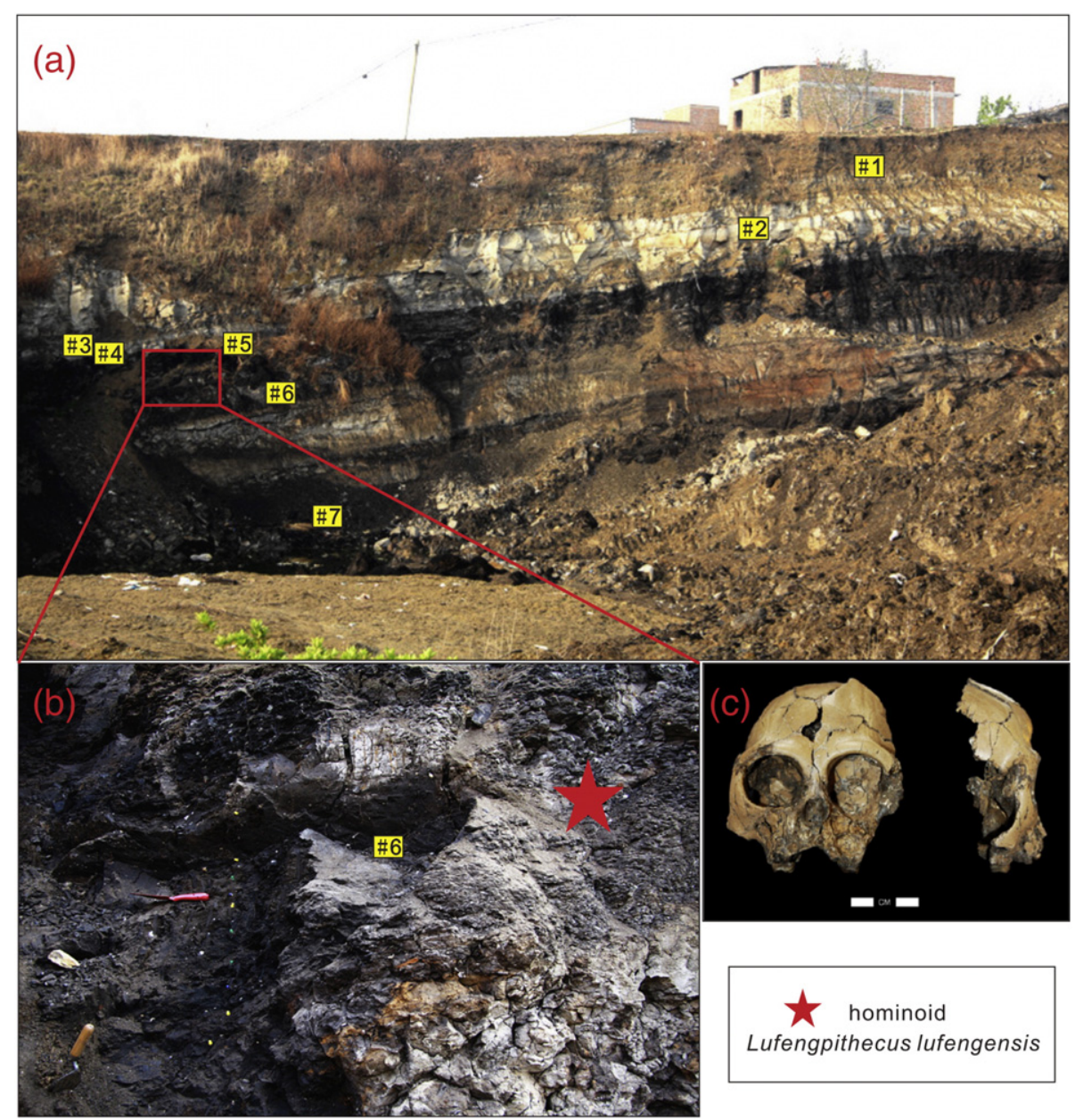

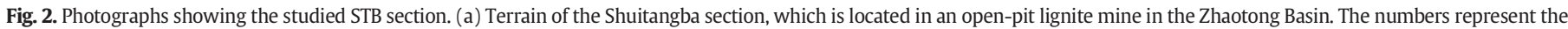

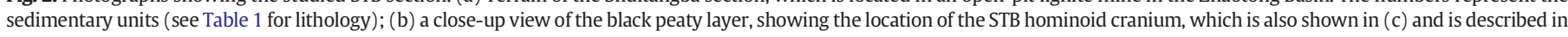
detail by Ji et al. (2013).

\subsubsection{Zone A (6 samples, $16.00-9.25 \mathrm{~m}$ )}

Arboreal pollen values are rather high (86.9-95.1\%) with an average of $92.1 \%$. Quercus E (23.1\% on average, the same below), Alnus (20.3\%) and Quercus D (7.4\%) are the dominant taxa. Herbaceous pollen (7.9\%) is also a major group, including Poaceae (6.1\%). Subzone A-1 is characterized by relatively stable pollen assemblages. In contrast, in subzone A-2, Alnus (21.3\%), Ilex (3.2\%), and Oleaceae (2.0\%) increase, and Quercus E (22.6\%), Quercus D (4.6\%), Poaceae (6.8\%) and Corylus (1.3\%) decrease; and ferns (17.1-8.0\%) decrease significantly and reach their minimum representation in the entire section. In addition, there is the significant presence of aquatic pollen (e.g., Potamogeton (0.4\%), Myriophyllum $(0.2 \%)$ and Typha $(0.1 \%))$.

Table 1

Lithology of the Shuitangba section.

\begin{tabular}{llr}
\hline Unit & Lithology & \multicolumn{1}{l}{ Depth } \\
\hline Overlying strata: cultivated soil & \\
$\# 1$ & Grey or yellowish-grey clays & $0-2.7 \mathrm{~m}$ \\
$\# 2$ & Grey clayey silts & $2.7-5.4 \mathrm{~m}$ \\
$\# 3$ & Gravels & $5.4-5.9 \mathrm{~m}$ \\
$\# 4$ & Clayey silts containing a large number of fossil shellfish & $5.9-6.4 \mathrm{~m}$ \\
$\# 5$ & Middle lignite layer & $6.4-7.6 \mathrm{~m}$ \\
$\# 6$ & Black peaty clay containing hominoid fossils & $7.6-12.3 \mathrm{~m}$ \\
$\# 7$ & Lower lignite layer & $12.3-16 \mathrm{~m}$ \\
Underlying strata: lignite & \\
\hline
\end{tabular}

\subsubsection{Zone B (14 samples, $9.25-8.70 \mathrm{~m}$ )}

This zone comprises the critical part of the section, from which the STB hominoid was excavated (Fig. 4). Broad-leaved tree pollen taxa (71.0\%) increase, while conifers $(17.0 \%)$ remain at a low value. Herbaceous pollen increases to the highest value (18.1\%) for the entire section. Quercus E (39.4\%), Poaceae (9.8\%) and Carya (4.1\%) increase significantly. However, Alnus (7.4\%), Quercus D (7.4\%), Tsuga (5.6\%), Pinus (4.5\%), Castanea/Castanopsis (2.0\%), Ilex (1.7\%), Corylus (1.7\%), Ulmus (1.6\%), Carpinus (1.4\%), Eriaceae (1.1\%) and Oleaceae $(0.8 \%)$ remain at low levels. Other groups, such as aquatics (1.4\%), with Trapa (0.9\%) as the main genus, and ferns (10.0\%), increase gradually although they remain at a low level.

\subsubsection{Zone C ( 7 samples, $8.70-2.00 \mathrm{~m}$ )}

This zone is divided into two subzones, based on the significant changes in taxa such as Quercus, Tsuga, Alnus, Castanea/Castanopsis and Poaceae (Fig. 3).

Subzone C-1 (3 samples, 8.70-6.10 m): Coniferous pollen (31.7\%) gradually increases, while other groups consisting of broad-leaved trees $(64.2 \%)$, herbs $(4.1 \%)$ and aquatics $(0.2 \%)$, decrease to varying degrees. Examples of taxa in these groups include Quercus E (25.1\%), Poaceae (2.9\%), Carya (0.3\%), Ilex (0.6\%), Oleaceae (0.2\%) and Ericaceae (0.2\%). However, Quercus D (9.1\%), Apiaceae (2.1\%), Larix $(1.8 \%)$ and Ulmus (1.8\%) increase, and Tsuga (15.9\%) and Alnus (17.2\%) increase significantly. Ferns increase to their highest value (35.0\%) for the entire section. 


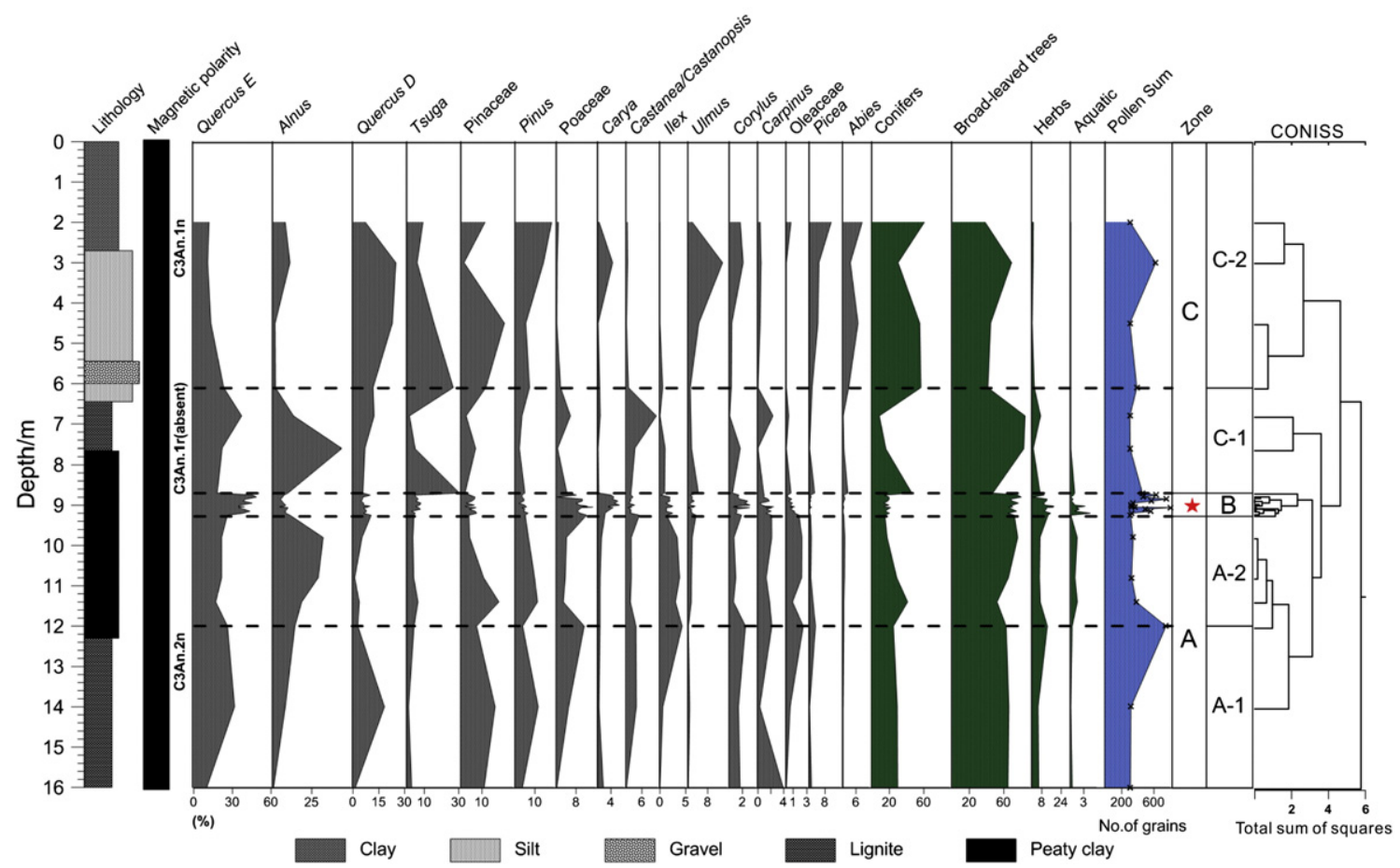

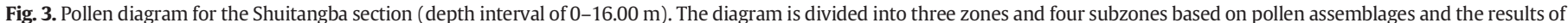
cluster analysis.

Subzone C-2 (4 samples, $6.10-2.00 \mathrm{~m}$ ): The top of Zone C is characterized by the increase of conifers (50.7\%), and the decrease of broad-leaved trees (48.4\%) and herbs (0.9\%). Quercus D (16.6\%), Quercus E (14.8\%), Tsuga (14.3\%), Pinus (11.4\%) and Picea-Abies (10.8\%) are the dominant species, together with Alnus (5.4\%), Ulmus (5.2\%), Larix (1.5\%), Carya (1.3\%), Keteleeria (1.2\%), Corylus (1.1\%), Liquidambar (1.0\%), Poaceae (0.7\%), Pterocarya (0.6\%), Castanea/Castanopsis ( $0.4 \%)$, Carpinus $(0.3 \%)$ and ferns (7.2\%). The pollen of aquatic taxa disappeared completely.

\subsection{Principal component analysis (PCA)}

PCA of the pollen data can potentially improve the palaeoclimatic interpretation of the established pollen zones. Fig. 5 exhibits a PCA biplot based on the pollen percentages. The first principal component, Axis 1 , has an eigenvalue of 0.46 . Temperate taxa, especially Alnus, as well as the cold-mesic conifers Tsuga and Pinus, have the highest positive loadings on Axis 1; whereas the subtropical evergreen taxa, Quercus

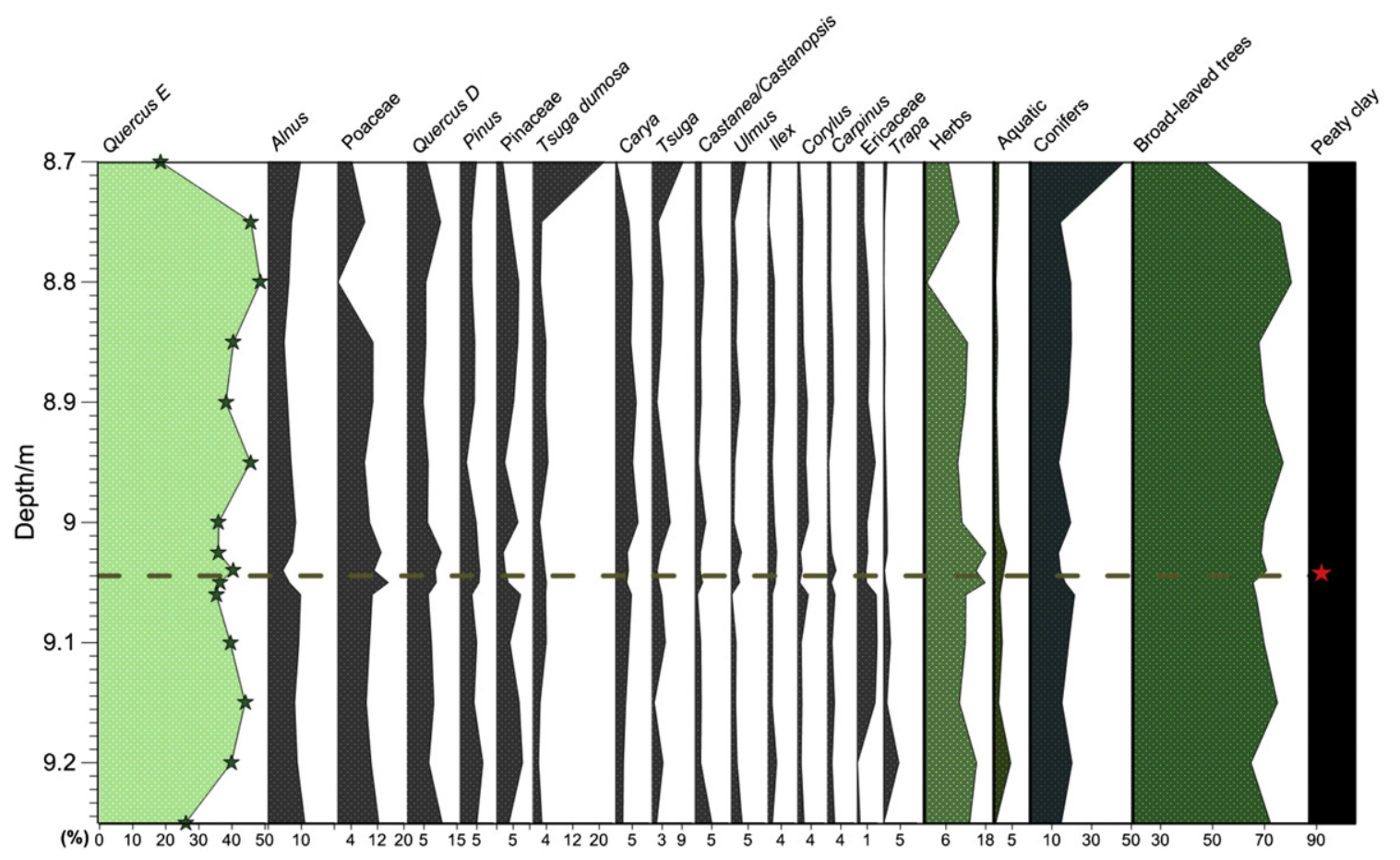

Fig. 4. Pollen diagram of the hominoid-bearing layer (8.70-9.25 m). 
(a)

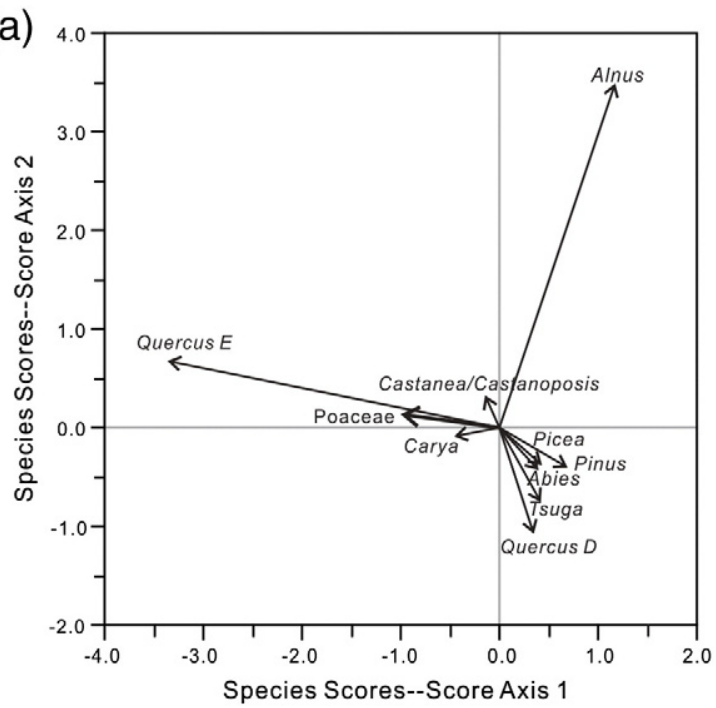

(b)

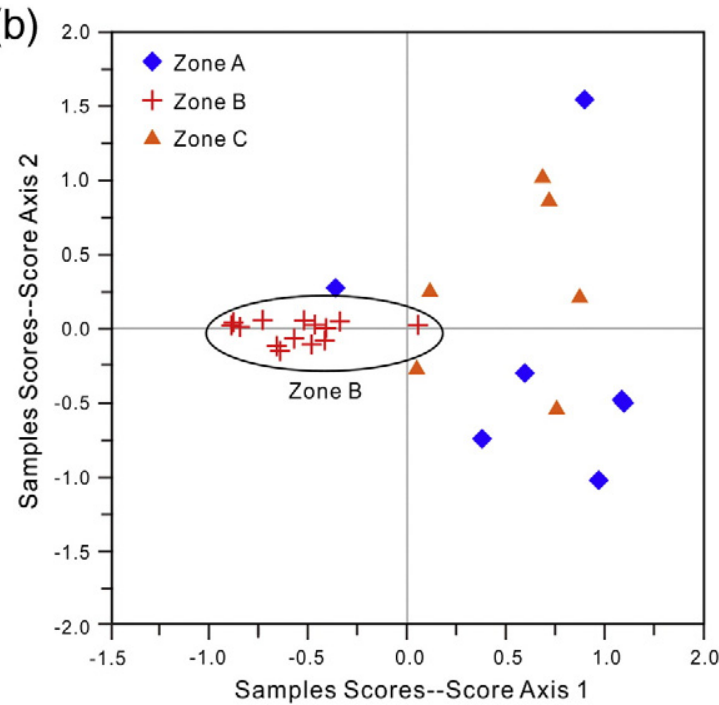

Fig. 5. Results of principal component analysis (PCA) of the pollen data: (a) species and (b) samples score loadings on axes 1 and 2.

E, Carya, and Castanea/Castanopsis have the highest negative loadings on Axis 1. Negative loadings on Axis 1 represent a warmer climate, and positive loadings represent cooler conditions. Compared with pollen Zones A and C, Zone B, marked by the highest sample scores on Axis 1, exhibits an increasing trend from 9.25 to $8.7 \mathrm{~m}$, representing the warmest climate (Fig. 6).

\section{Discussion}

\subsection{Taphonomy of pollen versus vertebrate fossils}

The taphonomy of the vertebrate fossils excavated from the STB section, including the ape fossil, was analyzed in detail by Jablonski

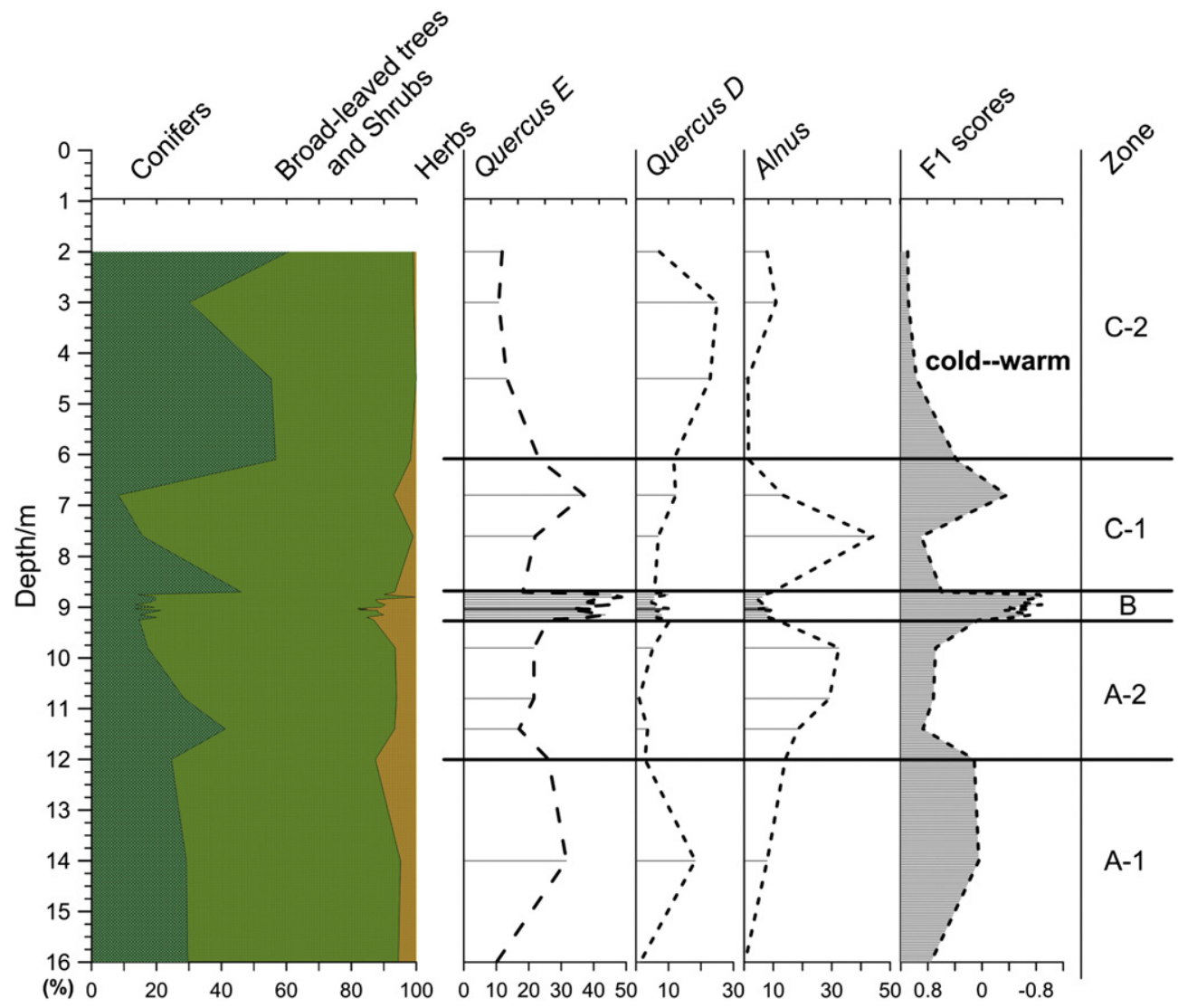

Fig. 6. Comparison of the pollen percentages of major taxonomic groups and selected individual taxa and PCA sample scores on Axis 1 . 
et al. (2014), and is briefly summarized here. Most of the vertebrate fossils were recovered in situ, occurring in the peaty clay layer bearing the hominoid (Unit \#6 in Table 1 and Fig. 2), between the lower and middle layers of lignite. Of the total number of collected specimens, $84.4 \%$ are postcranial, $2 \%$ are cranial, and $13.6 \%$ are dental, leading Jablonski et al. (2014) to suggest that the animals were not disturbed prior to burial. In addition, taphonomic observations by the authors on the large-mammal specimens indicate the lack of, or minimal, weathering and low occurrence of damage to bones caused by animal gnawing or trampling, further leading them to suggest that the large mammals were buried relatively quickly after death and remained relatively undisturbed.

The STB sedimentary sequence comprises clays, silts, peaty clays and lignites of lacustrine or swampy origin (Ji et al., 2013; Jablonski et al., 2014). Only a thin layer of gravels of local occurrence and with thicknesses of $5 \sim 50 \mathrm{~cm}$ is present in the section (Unit \#3 in Table 1 and Fig. 2). Until now, no large and perennial fluvial systems have been recognized in the late Neogene deposits of the Zhaotong Basin. Moreover, the samples analyzed were collected from the vicinity of the STB hominoid fossil site (Fig. 2), and the palynological results indicate that the dominant genera in this assemblage are species with local distributions. Considering the aforementioned taphonomic features of vertebrate fossils, together with the sedimentological data, we suggest that the sediments and associated fossil pollen of the STB section accumulated in situ and were not transported a long distance, and therefore that they can be used reliably to reconstruct the palaeovegetation.

\subsection{Vegetation and climatic history recorded in the STB section}

Prior to the presence of the hominoid (Zone A), the vegetation was dominated by broad-leaved taxa, e.g. Quercus E, Castanea/Castanopsis, and Quercus D. In addition, the aquatic taxa in subzone A-2 and Zone B suggest the presence of lake and/or swamp environments within the basin. The pollen assemblage of this zone indicates the development of sparse evergreen and deciduous broad-leaved mixed forest, including Quercus E, Alnus, Quercus D, Carpinus, Castanea/Castanopsis, Corylus and Carya. Mixed needle and broad-leaved forest with Ilex and Ericaceae grew in high altitude areas. This was a transitional period involving a shift to habitats suitable for the STB hominoid.

During the period when the hominoid lived (Zone B), the pollen stratigraphy changes gradually, indicating a stable vegetation community. Arboreal pollen exceeds $80 \%$, characterized by a high proportion of evergreen arboreal taxa, e.g., Quercus E. The proportion of herbaceous pollen is about $10 \%$, and aquatic components, including Typha, Potamogeton and Myriophyllum, increase to $1.3 \%$. This pollen assemblage suggests typical evergreen broad-leaved forest with grasses widely distributed in the open space understory or at the woodland edges. The deciduous broad-leaved forest probably grew on hillsides at low altitudes, and the coniferous trees (Pinus and Tsuga) and shrubs (Ilex and Ericaceae) probably grew at high altitudes on the mountains. The PCA factor scores on Axis 1 (F1 scores) are characterized by relatively high values with a slight increase during this period, suggesting a warm climate in the terminal Miocene in the Zhaotong Basin.

After the disappearance of the STB hominoid (Zone C), a marked change in the character of the vegetation occurred. Ulmus, Quercus D and conifers increased and Quercus E, Castanea/Castanopsis, herbaceous and aquatic taxa decreased, indicating a trend towards a cooler and drier climate in the Zhaotong Basin and a colder and wetter climate around the hills, showing the characteristic of the vertical vegetation zonation.

Much previous research has shown that northern Yunnan was already at a high altitude during the late Miocene and that the diversification of vegetation types had occurred (Wang et al., 2012; Jacques et al., 2013, 2014). In our study, the vertical vegetation characteristic of Zones A and B and subzone C- 1 are not obvious, while after the disappearance of the STB hominoid (subzone $\mathrm{C}-2$ ), coniferous trees increased significantly, indicating the occurrence of rich and diverse vegetation types. In subzone C-2, Picea and Abies increased sharply. These genera usually grow in high mountains at above $3600 \mathrm{~m}$ a.s.l., while Tsuga occurs in the region of $\sim 3000 \mathrm{~m}$ a.s.l. Pine forest and mixed forest are distributed widely in the $\sim 1000-3000 \mathrm{~m}$ a.s.l. region, and in addition the dominant representative species from Quercus $D$ grow within the range of 2000-1000 m a.s.l. In contrast, most of the Ulmus species mainly grow at $\sim 500 \mathrm{~m}$ a.s.l. The phenomenon, the mixed growth of a variety of plants growing at different altitudes, reveals the characteristic of the vertical vegetation zonation.

Based on a comparison of the percentages of herbs, broad-leaved trees and conifers between the different pollen zones (Fig. 3), we conclude that prior to the appearance of the STB hominoid (Zone A), the Zhaotong Basin was mainly forested with subtropical evergreen broad-leaved taxa mixed with temperate deciduous components. However, the climate was cooling significantly at the time when the STB hominoid disappeared (Zone $\mathrm{C}$ ). As a preliminary conclusion, the palaeovegetation within the transitional zone (Zone B), evergreen broad-leaved forest with grasses was distributed within the basin and some deciduous broad-leaved trees and coniferous trees grew around, providing an optimum environment for the STB hominoid.

\subsection{The habitat of the STB hominoid}

We surmise that an environment characterized by several vegetation communities may have constituted a highly suitable habitat for the STB hominoid. In the Zhaotong Basin, the environment featured a variety of forest and woodland types comprising arboreal taxa (such as Quercus E, Alnus, Quercus D, Carya, Castanea/Castanopsis, Ilex, Oleaceae, Ulmus, Corylus and Carpinus), herbaceous taxa (such as Poaceae, Trapa and Polygonaceae), and ferns (such as Polypodiaceae, Davallia and Pteris). Furthermore, the presence of aquatic pollen in the hominoid-bearing layer indicates that the STB hominoid would have lived in the vicinity of lake and/or swamp. Based on the occurrence of the approximately coeval ape fossil remains at other sites in Yunnan (e.g., at Kaiyuan, Lufeng, Yuanmou and Baoshan) (Wu, 1957, 1958; Sun and Wu, 1980; Chen et al., 1986; Geng, 1994; Wang, 1996; Qian and Ling, 1998; Liu et al., 2002; Xia et al., 2009), lake or wetland environments were a common feature of this period. It is possible that in the warm and humid climate the hominoids lived in forest adjacent to open areas with some grasses growing. This scenario is consistent with our pollen-assemblage-based palaeovegetation reconstruction for the STB section, which indicates a warm and moist climate with typical evergreen broad-leaved forest with some herbs and ferns, and with lake and/or swamp environments in the vicinity. The palaeovegetation shift may have been a critical element in the survival and development of the STB hominoid.

The habitat of the STB hominoid inferred from our pollen data is highly consistent with that evidenced by the vertebrate fauna. Mammals represent about 25\% of the vertebrate fauna and aves represent about 63\% (Jablonski et al., 2014). The mammals, including the ape, tapirs, various insectivores, flying squirrels, and the bamboo rat, indicate a densely vegetated, moist-forest palaeoenvironment, as further evidenced by the occurrence of plentiful remains of large tree trunks (Jablonski et al., 2014). Noteworthy among the features of the STB vertebrate fauna is the dominance and diversity of freshwater birds (Zhang et al., 2013; Jablonski et al., 2014). The frequency of piscivorous diving birds (Li Zhiheng, personal communication) indicates relatively deep, large and permanent water bodies (e.g., lakes). In addition, the abundance of fish, frog, turtle and crocodile remains, and beaver and otter-like mustelids indicate a depositional environment at the margin of standing water (Jablonski et al., 2014). In addition, the occurrence of terrestrial birds (e.g, Galliformes) and other waders (e.g., Ciconiiformes, Pelecaniformes, Gruiformes, Charadriiformes) usually suggests the presence of shaded shrubland or some open spaces (Zhang et al., 2013). Therefore, the faunal assemblage from the STB hominoid site is indicative of a forest habitat 
accompanied by open shrubland adjacent to lacustrine or swampy environments.

4.4. The relationship between palaeoenvironment/vegetation and hominoid in Africa and southwest China during the late Miocene

Since the mid-Miocene, the Earth has experienced a general cooling trend accompanied by regional aridification events (e.g., Miller et al., 1987; Zachos et al., 2001). It is hypothesized that the uplift of the Tibetan Plateau and the consequent increase in chemical weathering rate was probably one of the major causes of the global Cenozoic cooling trend through the drawdown of atmospheric $\mathrm{CO}_{2}$ (Ruddiman and Kutzbach, 1990; Raymo and Ruddiman, 1992; Zachos et al., 2001). Against this background of global cooling, and the attendant environmental changes, the number of ape taxa decreased sharply worldwide, becaming rare in Africa and southwest China (Harrison et al., 2002). In addition, the late Miocene was the critical period for the divergence of the last common ancestor of humans and apes (Brunet et al., 2002; Langergraber et al., 2012). Therefore, a comparison of the palaeoenvironment and vegetation of Africa and southwest China in the late Miocene could make a significant contribution to our understanding of the palaeoenvironment of the STB hominoid and could further help explain the occurrence of the 'refugium' for hominoids in southwest China.

Climatic cooling promotes acidifications and changes in vegetative structure. The landscape of Africa, especially East Africa, has been significantly reshaped over the last 10 million years, changing from a relatively flat, homogenous region covered with mixed tropical forest, to a varied and heterogeneous environment (Maslin et al., 2014). Since the Miocene, one of the most important trends in vegetation has been the development of extensive $C_{4}$ ecosystems (Cerling et al., 1993). Simultaneously in both West and East Africa, a prominent vegetation change took place between 6.3 and $6 \mathrm{Ma}$ (Bonnefille, 2010), characterized by a trend of significantly decreasing tree cover. At that time, very arid conditions, evidenced by sparse tree cover, occurred over the entire tropical region (Bonnefille, 2010). The taxonomic composition of the Miocene fossil wood flora from Ethiopia and Uganda (Duperon-laudoueneix and Duperon, 1995; Bonnefille, 2010) is indicative of mixed evergreen and deciduous forests, and the identification of Trapa, and Poaceae (grass) are indicative of herbaceous and aquatic plants surrounding pond or shallow lake environments. In East Africa, ${ }^{13} \mathrm{C} /{ }^{12} \mathrm{C}$ data also point to the prevalence of open environments at the majority of hominin fossil sites over the past 6 million years (Cerling et al., 2011). The record reveals a period characterized by relatively sparse woodland cover in the late Miocene to early Pliocene (Cerling et al., 2011), or by $\mathrm{C}_{4}$ grasslands and wooded grasslands (WoldeGabriel et al., 2009). The types of habitats associated with late Miocene to early Pleistocene hominoids and hominins in Africa range from sparse woodland to more open environments (Elton, 2008).

Since significant tree coverage, either woodland or forest, was likely to have been an important component of hominoid and hominin environments from the Miocene to the Pleistocene (Andrews, 1989; Pickford and Senut, 2001; Vignaud et al., 2002; WoldeGabriel et al., 2009), it is possible to speculate that the switch of habitat in Africa from closed to open environments, caused by climatic cooling, increasing aridity and the development of $\mathrm{C}_{4}$ grasslands, may have provided the backdrop for the early stages of hominid evolution in Africa. However, this trend may also force the apes to change their behavior and to influence on morphology (Elton, 2008).

In Asia, the Asian monsoon was established during the period from the late Oligocene to the early Miocene (Guo et al., 2002; Clift et al., 2008), and probably reached maximum strength around 7-8 Ma (Quade et al., 1989; An et al., 2001). The results of the analysis of deep-sea benthic foraminferal species diversity indicate that the southwest monsoon system appeared as early as the late Middle Miocene, and that it intensified significantly in the late Miocene when the modern southwest monsoon regime became permanently established (Singh and Gupta, 2004,
2005). However, the African summer monsoon weakened drastically during the Tortonian ( 7-11 Ma), resulting in the expansion of the Sahara desert, as evidenced from climate model simulations (Zhang et al., 2014). Thus these significant climatic changes during the late Miocene probably caused the different shift in Asia and Africa, and the persisting strength Asian monsoon system possible links to the survival of hominoids in Yunnan. In general, most of southwest China was warm and humid during the Miocene (Yao et al., 2011), with a mixture of broad-leaved evergreen forests and mixed mesophytic forests in the late Miocene (Jacques et al., 2011; Biasatti et al., 2012). However, previous qualitative studies reveal several differences in the composition of vegetation in the basins where hominoid Lufengpithecus lived, as outlined below.

The Xiaolongtan Basin (Fig. 1) was occupied by a densely vegetated, semi-moist evergreen broad-leaved forest, accompanied by a few deciduous trees (Wang, 1996; Xia et al., 2009) from the late Middle Miocene to the early Late Miocene ( $\mathrm{Li}$ et al., 2015), the period when the hominoid Lufengpithecus keiyuanensis lived there. In the Yuanmou Basin (Fig. 1), the vegetation was primarily pine forest with deciduous broad-leaved trees as a major component of woodland, while Quercus E was rare (Pan and Zong, 1993; Qian and Ling, 1998; Liu et al., 2002; $\mathrm{Ni}$ and Qiu, 2002) in the middle Late Miocene (Yue et al., 2004; Zhu et al., 2005), when the hominoid Lufengpithecus hudienensis lived there. Another significant feature of the Yuanmou Basin is that Artemisia and Chenopodiaceae, which like arid climate, made up a relatively large portion of angiosperm, indicating the existence of large area of grassland (Qian and Ling, 1998). These, combing with the results of sedimentological data and faunal assemblage, indicate thick forest as well as more open areas under a warm and humid climate for Yuanmou hominoid. In the Lufeng Basin in the late Late Miocene (Flynn and Qi, 1982), the hominoid lived in a moist southern subtropical-tropical environment, in mixed woodland at the edge of forest with Myrica and Alnus as the dominant taxa (Sun and Wu, 1980; Qiu et al., 1985; Chen et al., 1986). In the Baoshan Basin, the hominoid, possibly of Mio-Pliocene age, lived in a dense forest with a shrub and grass understory, and with mixed needle and broad-leaved trees growing in the vicinity (Geng, 1994). In the Zhaotong Basin, our new pollen data indicate that in the terminal Miocene the vegetation was dominated by evergreen broad-leaved forests, accompanied by grasses.

From the foregoing floristic comparisons, it is clear that the palaeovegetation of the hominoid Lufengpithecus gradually evolved from dense forest to mixed forest and woodland, which are relatively sparse, with an increasing representation of plants taxon like cool and arid climate, including temperate deciduous trees, herbs and conifers. The change from subtropical to temperate vegetation zones and from broad-leaved to needle-leaved vegetation types represents a significant shift in environmental conditions. These changes could have been caused by global cooling in the late Miocene (Zachos et al., 2001) or by regional uplift of the southeastern margin of the Tibetan Plateau (Harrison et al., 1992). Tectonic movements and fluvial dynamics both contributed to the evolution of endemic species in Yunnan (Qiu et al., 2011). During the Neogene, the eastward and southeastward expansion of the Tibetan Plateau resulted in the uplift of parts of Yunnan (Jacques et al., 2014), and therefore the Zhaotong, Yuanmou, Lufeng and Xiaolongtan Basins adjacent to or within the Xianshuihe-Xiaojiang fault system, and the Baoshan Basin adjacent to the Gaoligong Shear Zone could have been significantly affected. The survival of the Yunnan hominoids may have benefited from episodes of uplift in the southeastern margin of the Tibetan Plateau and/or lateral movements along major fault systems (e.g., the Xianshuihe-Xiaojiang fault system and the Gaoligong Shear Zone), which would have isolated the hominoids geographically and ecologically (Harrison et al., 2002; Zhu et al., 2005; Harrison, 2006; Ji et al., 2013).

Clearly, several lines of evidence indicate that the habitats of the Yunnan hominoids differ from those of contemporary hominoids and hominins in Africa. The Yunnan hominoids, including the STB hominoid, lived in arboreal subtropical-tropical environments, particularly 
woodlands/forests, similar to those in Africa in the early Miocene (Andrews and Humphrey, 1999). Modern behavioural studies indicate that woodlands and grasslands provide abundant sources of readily accessible foods for terrestrial primates (Altmann, 1998). Therefore, we speculate that the abundance of $C_{3}$ plants (trees), and the complementary $\mathrm{C}_{4}$ resources, would have increased the adaptive flexibility of hominoids. In addition, the warm and humid climatic conditions during the terminal Miocene (Figs. 3, 6), may have favoured the occurrence of the hominoid in the Zhaotong Basin.

\section{Conclusions}

The results of pollen analysis of the STB section in the Zhaotong Basin, on the southeastern margin of the Tibetan Plateau, suggest a progressive change in hominoid habitats during the terminal Miocene. The vegetation changed from a subtropical evergreen broad-leaved forest to broad-leaved and coniferous forest, indicating a cooling trend. The environment of the STB hominoid consisted of typical evergreen broad-leaved forest, together with herbs and ferns, accompanied by open shrubland area adjacent to lacustrine or swampy environments, thus revealing a warm and humid climate. We speculate that the diversity of the vegetation and the environment, and the overall warm-humid climate during the terminal Miocene, would have increased the adaptive flexibility of the hominoids, and may have favoured their occurrence in the Zhaotong Basin. Our findings provide an important palaeoenvironmental context for exploring the evolutionary processes of the late Miocene hominoids in the southeastern margin of the Tibetan Plateau.

\section{Acknowledgements}

We are grateful to Professor Rick Potts, Dr. Xu Deke and Dr. Li Zhiheng for helpful discussions and to Professor Kong Zhaochen for the help of pollen identification. This study was financially supported by the "Strategic Priority Research Program" of the Chinese Academy of Sciences (Grant No. XDB03020500). XJ was supported by the Yunnan Natural Science Foundation (Grant No. 2010CC010) and Zhaotong Government. CD acknowledges further partial support from the National Key Basic Research Program of China (Grant No. 2012CB821900).

\section{References}

Agustí, J., Cabrera, L., Garces, M., Parés, J.M., 1997. The Vallesian mammal succession in the Vallès-Penedès basin (northeast Spain): Paleomagnetic calibration and correlation with global events. Palaeogeogr. Palaeoclimatol. Palaeoecol. 133, 149-180.

Altmann, S.A., 1998. Foraging for survival: Yearling baboons in Africa. University of Chicago Press, Chicago, pp. 1-536.

An, Z.S., Kutzbach, J.E., Prell, W.L., Porter, S.C., 2001. Evolution of Asian monsoons and phased uplift of the Himalaya-Tibetan plateau since Late Miocene times. Nature $411,62-66$.

An, Z.S., Huang YS, Liu, W.G Guo, ZT, Clemens, S, Li, L, Prell, W Ning Y. , Cai, YJ, Zhou, W.J., Lin, B.H., Zhang, Q.L., Cao, Y.N., Qiang, X.K., Chang, H., Wu, Z.K., 2005. Multiple expansions of C4 plant biomass in East Asia since 7 Ma coupled with strengthened monsoon circulation. Geology 33, 705-708.

Andrews, P., 1989. Palaeoecology of Laetoli. J. Hum. Evol. 18, 173-181.

Andrews, P., 1992. Evolution and environment in the Hominoidea. Nature 360, 641-646.

Andrews, P., Humphrey, L., 1999. African Miocene environments and the transition to early hominines. In: Bromage, T.G., Schrenk, F. (Eds.), African biogeography, climate change and early hominid evolution. Oxford University Press, New York, pp. 282-300.

Antón, S.C., Potts, R., Aiello, L.C., 2014. Evolution of early Homo: An integrated biological perspective. Science 345. http://dx.doi.org/10.1126/science.1236828 (1236828-1-1236828-11).

Begun, D.R., 2002. European hominoids. In: Hartwig, W.C. (Ed.), The primate fossil record. Cambridge University Press, Cambridge, England, pp. 339-368.

Benefit, B.R., McCrossin, M.L., 1995. Miocene hominoids and hominid origins. Annu. Rev. Anthropol. 24, 237-256.

Bernor, R.L., Kordos, L., Rook, L., Agustí, J., Andrews, P., Armour-Chelu, M., Begun, D.R. Cameron, D.W., Damuth, J., Daxner-Höck, G., Bonis, L., Fejfar, O., Fessaha, N., Fortelius, M., Franzen, J., Gasparik, M., Gentry, A., Heissig, K., Hernyak, G., Kaiser, T., Koufos, G., Krolopp, E., Jánossy, D., Llenas, M., Meszáros, L., Müller, P., Renne, P., Roček, Z., Sen, S., Scott, R., Szyndlar, Z., Topál, G., Ungar, P.S., Utescher, T., van Dam, J.A., Werdelin, L., Ziegler, R., 2004. Recent advances on multidisciplinary research at Rudabánya, Late Miocene (MN9), Hungary: A compendium. Palaeontogr. Ital. 89, 3-36.
Biasatti, D., Wang, Y., Gao, F., Xu, Y.F., Flynn, L., 2012. Paleoecologies and paleoclimates of late Cenozoic mammals from Southwest China: Evidence from stable carbon and oxygen isotopes. J. Asia Earth Sci. 44, 48-61.

Blois, J.L., Hadly, E.A., 2009. Mammalian response to Cenozoic climatic change. Annu. Rev. Earth Planet. Sci. 37, 181-208.

Bonnefille, R., 2010. Cenozoic vegetation, climate changes and hominid evolution in tropical Africa. Glob. Planet. Chang. 72, 390-411.

Bonnefille, R., Potts, R., Chalié, F., Jolly, D., Peyron, O., 2004. High-resolution vegetation and climate change associated with Pliocene Australopithecus afarensis. Proc. Natl. Acad. Sci. U. S. A. 101, 12125-12129.

Boschetto, H.B., Brown, F.H., McDougall, I., 1992. Stratigraphy of the Lothidok Range, northern Kenya, and K/Ar ages of its Miocene primates. J. Hum. Evol. 22, 47-71.

Brunet, M., Guy, F., Pilbeam, D., Mackaye, H.T., Likius, A., Ahounta, D., Beauvilain, A., Blondel, C., Bocherens, H., Boisserie, J.R., DeBonis, L., Coppens, Y., Dejax, J., Denys, C., Duringer, P., Eisenmann, V., Fanone, G., Fronty, P., Geraads, D., Lehmann, T., Lihoreau, F., Louchart, A., Mahamat, A., Merceron, G., Mouchelin, G., Otero, O., Campomanes, P.P., DeLeon, M.P., Rage, J.C., Sapanet, M., Schuster, M., Sudre, J., Tassy, P., Valentin, X., Vignaud, P., Viriot, L, Zazzo, A., Zollikofer, C., 2002. A new hominid from the Upper Miocene of Chad, Central Africa. Nature 418, 145-151.

Casanovas-Vilar, I., Alba, D.M., Garcés, M., Robles, J.M., Moyà-Solà, S., 2011. Updated chronology for the Miocene hominoid radiation in Western Eurasia. Proc. Natl. Acad. Sci. U. S. A. 108, 5554-5559.

Cerling, T.E., Wang, Y., Quade, J., 1993. Expansion of $C_{4}$ ecosystems as an indicator of global ecological change in the late Miocene. Nature 361, 344-345.

Cerling, T.E., Harris, J.M., MacFadden, B.J., Leakey, M.G., Quade, J., Eisenmann, V., Ehleringer, J.R., 1997. Global vegetation change through the Miocene/Pliocene boundary. Nature 389, 153-158

Cerling, T.E., Wynn, J.G., Andanje, S.A., Bird, M.I., Korir, D.K., Levin, N.E., Mace, W., Macharia, A.N., Quade, J., Remien, C.H., 2011. Woody cover and hominin environments in the past 6 million years. Nature 476, 51-56.

Chen, W.Y., Lin, Y.F., Yu, Q.L., 1986. On the paleoclimate during the period of Ramapithecus in Lufeng county, Yunnan province. Acta Anthropol. Sin. 5, 79-88 (in Chinese with English abstract)

Chou, M.Z., Zhai, R.J., 1962. Early Pleistocene mammals of Chaotung, Yunnan, with notes one some Chinese Stegodonts. Vertebrata PalAsiatica 6 (2), 138-147 (in Chinese with English abstract).

Clift, P.D., Hodges, K.V., Heslop, D., Hannigan, R., van Long, H., Calves, G., 2008. Correlation of Himalayan exhumation rates and Asian monsoon intensity. Nat. Geosci. 1, $875-880$.

Dai, S., Chou, C.-L., 2007. Occurrence and origin of minerals in a chamosite-bearing coal of Late Permian age, Zhaotong, Yunnan, China. Am. Mineral. 92, 1253-1261.

deMenocal, P.B., 2004. African climate change and faunal evolution during the PliocenePleistocene. Earth Planet. Sci. Lett. 220, 3-24.

Duperon-laudoueneix, M., Duperon, J., 1995. Inventory of mesozoic and Cenozoic woods from equatorial and northern equatorial Africa. Rev. Palaeobot. Palynol. 84 (3-4), 439-480.

Editorial Committee for Vegetation of Yunnan, 1987. Vegetation of Yunnan. Science Press, Beijing, pp. 1-1024 (in Chinese)

Elton, S., 2008. The environmental context of human evolutionary history in Eurasia and Africa. J. Anat. 212, 377-393.

Fægri, K., Iversen, J., 1975. Textbook of pollen analysis. Munksgaard, Copenhagen, pp. 1-295.

Flynn, L., Qi, G.Q., 1982. Age of the Lufeng, China, hominoid locality. Nature 298, 746-747.

Gebo, D.L., Maclatchy, L., Kityo, R., Deino, A., Kingston, J., Pilbeam, D., 1997. A Hominoid Genus from the Early Miocene of Uganda. Science 276, 401-404.

Geng, D.M., 1994. Evolutionary significance of fossil hominoid from Baoshan in researching the origin of human beings. Soc. Sci. Yunnan 1, 78-83 (in Chinese).

Guo, Z.T., Ruddiman, W.F., Hao, Q.Z., Wu, H.B., Qiao, Y.S., Zhu, R.X., Peng, S.Z., Wei, J.J., Yuan, B.Y., Liu, T.S., 2002. Onset of Asian desertification by 22 Myr ago inferred from loess deposits in China. Nature 416, 159-163.

Harrison, T., 2006. Taxonomy, phylogenetic relationships, and biogeography of Miocene hominoids from Yunnan, China. In: Decong, Yang (Ed.), Collected Works for "The 40th Anniversary of Yuanmou Man Discovery and the International Conference on Palaeoanthropological Studies". Yunnan Science and Technology Press, Kunming, pp. 233-249.

Harrison, T.M., Copeland, P., Kidd, W.S.F., Yin, A., 1992. Raising Tibet. Science 255, 1663-1670.

Harrison, T., Ji, X.P., Su, D.F., 2002. On the systematic status of the late Neogene hominoids from Yunnan Province. Chin. J. Hum. Evol. 43, 207-227.

Hilgen, F.J., Lourens, L.J., Van Dam, J.A., 2012. The Neogene Period. In: Gradstein, F.M., Ogg, J.G., Schmitz, M.D., Ogg, G.M. (Eds.), The Geologic Time Scale 2012. Elsevier BV, Amsterdam, the Netherlands, pp. 923-978.

Huang, Y., Clemens, S.C., Liu, W., Wang, Y., Prell, W.L., 2007. Large-scale hydrological change drove the late Miocene C4 plant expansion in the Himalayan foreland and Arabian Peninsula. Geology 35, 531-534.

Jablonski, N., Su, D., Flynn, L., Ji, X.P., Deng, C.L., Kelley, J., Zhang, Y.G., Yin, J.Y., You, Y.S., Yang, X., 2014. The site of STB (Yunnan, China) preserves a unique, terminal Miocene fauna. J. Vertebr. Paleontol. 34, 1251-1257.

Jacques, F.M.B., Shi, G., Wang, W.M., 2011. Reconstruction of Neogene zonal vegetation in South China using the Integrated Plant Record (IPR) analysis. Palaeogeogr. Palaeoclimatol. Palaeoecol. 307, 272-284.

Jacques, F.M.B., Shi, G.L., Wang, W.M., 2013. Neogene zonal vegetation of China and the evolution of the winter monsoon. Bull. Geosci. 88, 175-193.

Jacques, F.M.B., Su, T., Spicer, R.A., Xing, Y.W., Huang, Y.J., Zhou, Z.K., 2014. Late Miocene southwestern Chinese floristic diversity shaped by the southeastern uplift of the Tibetan Plateau. Palaeogeogr. Palaeoclimatol. Palaeoecol. 411, 208-215. 
Ji, X.P., Jablonski, N.G., Su, D.F., Deng, C.L., Flynnl, L.J., You, Y.S., Kelley, J., 2013. Juvenile hominoid cranium from the terminal Miocene of Yunnan, China. Chin. Sci. Bull. 58, 3771-3779.

Jiang, H.Q., 1980. Distributional features and zonal regularity of vegetation in Yunnan. Acta Bot. Yunnanica 2, 142-151 (in Chinese with English abstract).

Langergraber, K.E., Prüfer, K., Rowney, C., Boesch, C., Crockford, C., Fawcett, K., Inoue, E., Inoue-Muruyama, M., Mitani, J.C., Muller, M.N., et al., 2012. Generation times in wild chimpanzees and gorillas suggest earlier divergence times in great ape and human evolution. Proc. Natl. Acad. Sci. U. S. A. 109, 15716-15721.

Li, S.H., Deng, C.L., Yao, H.T., Huang, S., Liu, C.Y., He, H.Y., Pan, Y.X., Zhu, R.X., 2013. Magnetostratigraphy of the Dali Basin in Yunnan and implications for late Neogene rotation of the southeast margin of the Tibetan Plateau. J. Geophys. Res. Solid Earth 118, 791-807. http://dx.doi.org/10.1002/jgrb.50129.

Li, S.H., Deng, C.L., Dong, W., Sun, L., Liu, S.Z., Qin, H.F., Yin, J.Y., Ji, X.P., Zhu, R., 2015 Magnetostratigraphy of the Xiaolongtan Formation bearing Lufengpithecus keiyuanensis in Yunnan, southwestern China: Constraint on the initiation time of the southern segment of the Xianshuihe-Xiaojiang fault. http://dx.doi.org/ 10.1016/j.tecto.2015.06.002.

Liu, G.W., Li, D.Y., Huang, P., Fu, Q.L., 2002. A Pliocene flora from the Gantang formation of Yuanmou Basin, Yunnan province, SW China and its paleoclimate significance. Acta Palaeontol. Sin. 41, 1-9 (in Chinese with English abstract).

Maslin, M.A., Brierley, C.M., Milner, A.M., Shultz, S., Trauth, M.H., Wilson, K.E., 2014. East African climate pulses and early human evolution. Quat. Sci. Rev. 101, 1-17.

Miller, K.G., Fairbanks, R.G., Mountain, G.S., 1987. Tertiary oxygen isotope synthesis, sea level history, and continental margin erosion. Paleoceanography 2, 1-19.

Moyà-Solà, S., Köhler, M., Alba, D.M., Casanovas-Vilar, I., Galindo, J., 2004. Pierolapithecus catalaunicus, a new Middle Miocene great ape from Spain. Science 306, 1339-1344.

Ni, X.J., Qiu, Z.D., 2002. The micromammalian fauna from the Leilao, Yuanmou hominoid locality: Implications for biochronology and paleoecology. J. Hum. Evol. 42, 535-546.

Pan, Y.R., Zong, G.F., 1993. Stratigraphy and paleontology of the Yuanmou Basin, Yunnan Province, China (Chapter 4: paleontology, section 1: Mammalian faunas). In: Qian, F., Zhou, G. (Eds.), Quaternary Geology and Paleoanthropology of Yuanmou. Yunnan, China, pp. 19-28.

Pickford, M., Senut, B., 2001. The geological and faunal context of Late Miocene hominid remains from Lukeino, Kenya. C.R. Acad. Sci., Ser. Ila: Sci. Terre Planets 332, 145-152.

Potts, R., 2013. Hominin evolution in settings of strong environmental variability. Quat. Sci. Rev. 73, 1-13.

Qian, F., Ling, X.H., 1998. Living environment and time of Yuanmou hominoid fauna. J. Chengdu Univ. Technol. 25, 311-318 (in Chinese with English abstract)

Qiu, Z.D., Han, D.F., Qi, G.Q., Yufen, L., 1985. A preliminary report on a micromammalian assemblage from the hominoid locality of Lufeng Co. Yunnan Province. Acta Anthropol. Sin. 4, 13-32 (in Chinese with English abstract).

Qiu, Y.X., Fu, C.X., Comes, H.S., 2011. Plant molecular phylogeography in China and adjacent regions: tracing the genetic imprints of Quaternary climate and environmental change in the world's most diverse temperate flora. Mol. Phylogenet. Evol. 59, 225-244.

Qiu, Z.X., Qiu, Z.D., Deng, T., Li, C.K., Zhang, Z.Q., Wang, B.Y., Wang, X.M., 2013. Neogene land mammal stages/ages of China: toward the goal to establish an Asian land mammal stage/age scheme. In: Wang, X.M., Flynn, L.J., Fortelius, M. (Eds.), Fossil Mammals of Asia: Neogene Biostratigraphy and Chronology. Columbia University Press, New York, pp. 29-90.

Quade, J., Cerling, T.E., Bowman, J.R., 1989. Development of Asian monsoon revealed by marked ecological shift during the latest Miocene in northern Pakistan. Nature 342, 163-166.

Raymo, M.E., Ruddiman, W.F., 1992. Tectonic forcing of late Cenozoic climate. Nature 359, $117-122$.

Ruddiman, W.F., Kutzbach, J.E., 1990. Late Cenozoic plateau uplift and climate change. T. RSE. Earth 81, 301-314

Singh, R.K., Gupta, A.K., 2004. Late Oligocene-Miocene paleoceanographic evolution of the southeastern Indian Ocean: evidence from deep-sea benthic foraminifera (ODP Site 757). Mar. Micropaleontol. 51, 153-170.

Singh, R.K., Gupta, A.K., 2005. Systematic decline in benthic foraminiferal species diversity linked to productivity increases over the last $26 \mathrm{Ma}$ in the Indian Ocean. J. Foraminifer. Res. 35, 219-227.
Sun, X.J., Wu, Y.S., 1980. Paleoenvironment during the time of Ramapithecus Lufengensis. Vertebrata PalAsiatica 18, 247-255 (in Chinese with English abstract).

Traverse, A., 1988. Paleopalynology. Unwin Hyman, Boston, MA, pp. 1-600.

Vignaud, P., Duringer, P., Mackaye, H.T., Likius, A., Blondel, C., Boisserie, J., Bonis, L., Eisenmann, V., Etienne, M., Geraads, D., Guy, F., Lehmann, T., Lihoreau, F., Lopez-Martinez, N., MourerChauviré, C., Otero, O., Rage, J., Schuster, M., Viriot, L., Zazzo, A., Brunet, M., 2002. Geology and palaeontology of the Upper Miocene Toros-Menalla hominid locality, Chad. Nature 418, 152-155.

Wang, W.M., 1996. A palynological survey of Neogene strata in Xiaolongtan Basin Yunnan province of south China. Acta Bot. Sin. 38, 743-748 (in Chinese with English abstract).

Wang, J.Z., 2010. Preliminary evaluation on exploration prospect of CBM resources of the Neogene lignite in Shaotong Basin. China Coalbed Methane 7 (2), 3-6 (in Chinese with English abstract).

Wang, E., Burchfiel, B.C., Royden, L.H., Chen, L.Z., Chen, J.S., Li, W.X., Chen, Z.L., 1998. Late Cenozoic Xianshuihe-Xiaojiang, Red River, and Dali fault systems of Southwestern Sichuan and Central Yunnan, China. Geol. Sci. Am. Sci. 327, 1-108.

Wang, E., Kirby, E., Furlong, K.P., van Soest, M., Xu, G., Shi, X., Kamp, P.J.J., Hodges, K.V., 2012. Two-phase growth of high topography in eastern Tibet during the Cenozoic. Nat. Geosci. 5, 640-645.

Ward, S.C., Duren, D.L., 2002. Middle and late Miocene African hominoids. In: Hartwig, W.C. (Ed.), The primate fossil record. Cambridge University Press, Cambridge, England pp. 385-397.

WoldeGabriel, G., Ambrose, S.H., Barboni, D., Bonnefille, R., Bremond, L., Currie, B. DeGusta, D., Hart, W.K., Murray, A.M., Renne, P.R., Jolly-Saad, M.C., Stewart, K.M., White, T.D., 2009. The geological, isotopic, botanical, invertebrate and lower vertebrate surroundings of Ardipithecus ramidus. Science 326, 65e1-65e5.

Wood, B., Harrison, T., 2011. The evolutionary context of the first hominins. Nature 470 347-352.

Wu, R.K., 1957. Fossils teeth of Dryopithecus discovered in Kaiyuan, Yunnan province Vertebrata PalAsiatica 1, 25-32 (in Chinese).

Wu, R.K., 1958. New materials obtained from Dryopithecus discovered in Kaiyuan, Yunnan province. Vertebrata PalAsiatica 2, 38-43 (in Chinese).

Xia, K., Su, T., Liu, Y.S.C., Xing, Y.W., Jacques, F.M.B., Zhou, Z.K., 2009. Quantitative climate reconstructions of the late Miocene Xiaolongtan megaflora from Yunnan, southwest China. Palaeogeogr. Palaeoclimatol. Palaeoecol. 276, 80-86.

Xu, H.Y., Jiang, H.C., Mai, X.S., Ma, X.L., 2013. A new processing method for the pollen samples from Palaeogene red beds in the Liguanqiao Basin, Hubei Province, and Pleistocene loess from the Chinese Loess Plateau. Quat. Int. 286, 45-55.

Yao, Y.F., Bruch, A.A., Mosbrugger, V., Li, C.S., 2011. Quantitative reconstruction of Miocene climate patterns and evolution in Southern China based on plant fossils. Palaeogeogr. Palaeoclimatol. Palaeoecol. 304, 291-307.

Yue, L.P., Zhang, Y.X., Qi, G.Q., Heller, F.A., Wang, J.Q., Yang, L.R., Zhang, R., 2004. Paleomagnetic age and palaeobiological significance of hominoid fossil strata of Yuanmou Basin in Yunnan. Sci. China Ser. D Earth Sci. 47, 405-411.

Zachos, J., Pagani, M., Sloan, L., Thomas, E., Billups, K., 2001. Trends, rhythms, and aberrations in global climate 65 Ma to present. Science 292, 686-693.

Zhang, Y.G., Ji, X.P., Jablonski, N.G., Su, D.F., Wang, X.B., Yang, X., Li, Z.H., Fu, L.Y., 2013. Stratigraphic significance of the avian fauna from late Miocene of Zhaotong region, Yunnan province. Acta Palaeontol. Sin. 52 (3), 281-287 (in Chinese with English abstract).

Zhang, Z.S., Ramstein, G., Schuster, M., Li, C., Contous, C., Yan, Q., 2014. Aridification of the Sahara desert caused by Tethys Sea shrinkage during the Late Miocene. Nature 513, 401-404.

Zhu, R.X., Liu, Q.S., Yao, H.T., Guo, Z.T., Deng, C.L., Pan, Y.X., Lu, L.Q., Chang, Z.G., Gao, F., 2005. Magnetostratigraphic dating of hominoid-bearing sediments a Zhupeng, Yuanmou Basin, southwestern China. Earth Planet. Sci. Lett. 236, 559-568

Zhu, R.X., Potts, R., Pan, Y.X., Lü, L.Q., Yao, H.T., Deng, C.L., Qin, H.F., 2008. Paleomagnetism of the Yuanmou Basin near the southeastern margin of the Tibetan Plateau and its constraints on late Neogene sedimentation and tectonic rotation. Earth Planet. Sci. Lett. 272, 97-104. 